\title{
Forum
}

\section{The defence of conservation is not an attack on the poor}

\author{
Steven Sanderson and Kent Redford
}

The relationship between poverty alleviation and biodiversity conservation continues to vex conservationists and social analysts alike. The three responses to our earlier Guest Editorial (Sanderson \& Redford, 2003) help refine the arguments and shape the angles from which to approach the debate, but neither the editorial nor the responses satisfy entirely. What missing pieces must be found and fitted to the puzzle?

Roe \& Elliott (2004) rightly suggest that the Millennium Development Goals and their implementation are unlikely to be effective for both conservation and poverty reduction. Conservationists and ecological economists continue to be frustrated by inattention to biodiversity values in development planning. Moreover, the world seems inattentive to the relationships between rural development and poverty alleviation, much less their connection to protected areas (Frison et al., 2004). Our view of the credibility of the Millennium Development Goals is affected by what appears to be unwarranted confidence in implementing sustainable solutions. The fact that biodiversity appeared as one of the major issues at the Johannesburg summit gives little comfort in the absence of coherent conservation action.

Our lament is not that poverty should be ignored; it is that protected areas are on the defensive, described as obstacles to poverty alleviation (Cernea \& SchmidtSoltau, 2003; McShane, 2003) or threats to indigenous peoples (WRM, 2002). It is equally lamentable that the World Parks Congress issued a commitment 'that protected area management strives to reduce, and in no way exacerbates, poverty' (Brockington \& Schmidt-Soltau, 2004). How can this principle stand? If areas of high conservation priority are encroached, or endangered wildlife harvested, can those charged with protected areas management ignore destructive practices so as to avoid negative economic impacts? If so, we will watch as wetlands are drained, turtles sold to market, primates smoked for sale in cities, and sharks stripped of their fins for soup. All of these activities contribute in some measure to rural incomes, often substantially.

Steven Sanderson (Corresponding author) and Kent Redford Wildlife Conservation Society, Bronx, N.Y. 10460, USA. E-mail ssanderson@wcs.org Received 20 February 2004. Accepted 23 February 2004.
It is clear that development has failed the truly poor. Citing aggregate gains cannot diminish the failure. If it is true that global fisheries produce food for a billion people and employment for 200 million (Roe \& Elliott, 2004), the case cannot be made that global fisheries development has helped the truly poor or guaranteed sustainability. The same can be said of agricultural growth and of forestry in the tropics. How is it, for example, that India has become a model of agricultural modernization, and in some cases conservation, and still fails to provide its poorest with the most modest hunger relief? Brazil, China and Mexico can also be counted amongst the most successful growth models in the developing world, and among the countries most inattentive to their rural poor.

At the core of the growth-development-poverty alleviation-conservation nexus lies the intractable problems of distributing the benefits of economic growth and ensuring conservation outcomes over large temporal and spatial scales, all the while working in small, highly distinctive, local situations, most often among the powerless (Kepe et al., 2004; Brockington \& Schmidt-Soltau, 2004). As conservationists we have neither the legitimacy nor the power to redress the distributive inequalities nor the damages of development in our work. The global economy and its development agents seem ill-disposed to attend to such a radical agenda themselves, but that shortcoming can hardly be placed at the door of conservationists.

Still, as we and our respondents have tried to suggest, much can be done. To Kepe's statement that 'there are no straightforward answers' we could add 'except in specific sites and communities.' Sustainability, conservation and poverty alleviation are abstractions; the lives of the poor and of wildlife are lived in specific places and times. We must stay in the field to build the partnerships of which we wrote in our editorial. Conservationists must conduct themselves openly and with sensitivity toward the powerless and poor. Our projects must be accountable and open, and our practices based on sound principles proven in practice. But critics of conservation must adhere to similar standards. The future of funding for truly progressive and socially compassionate conservation cannot rise or fall on the unspecified scepticism or anecdotal critiques of its opponents. Nor can protected areas weather another round as scapegoats for failed models of economic development. 


\section{References}

Brockington, D. \& Schmidt-Soltau, K. (2004) The social and environmental impacts of wilderness and development. Oryx, 38, 140-142.

Cernea, M. \& and Schmidt-Soltau, K. (2003) The end of forced resettlements for conservation: conservation must not impoverish people. Policy Matters, 12, 42-51.

Frison, E.A., Cherfas, J., Eyzaguirre, P.B. \& Johns, T. (2004) Biodiversity, Nutrition and Health: Making A Difference to Hunger and Conservation in the Developing World. Keynote Address to the Seventh Meeting of the Conference of the Parties to the Convention on Biological Diversity (COP 7), February 2004.
Http:/ / www.biodiv.org/doc/speech/2004/sp-2004-02-09cop-02-en.pdf [accessed 24 February 2004].

Kepe, T., Saruchera, M. \& Whande, W. (2004) Poverty alleviation and biodiversity conservation: a South African perspective. Oryx, 38, 143-145.

McShane, T. (2003) Protected areas and poverty. Policy Matters, $12,52-3$.

Roe, D. \& Elliott, J. (2004) Poverty reduction and biodiversity conservation: rebuilding the bridges. Oryx, 38, 137-139.

Sanderson, S.E. \& Redford, K. (2003) Contested relationships between biodiversity conservation and poverty alleviation. Oryx, 37, 389-390.

WRM (World Rainforest Movement) (2002) Panama: Protected Areas vs. Indigenous Peoples. World Rainforest Movement bulletin $N^{\circ}$ 57, April 2002. 